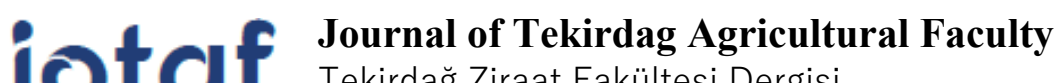 \\ Tekirdağ Ziraat Fakültesi Dergisi
}

\section{Bioactive Properties Of Commercial Reishi Mushroom Products In Powder Form}

\author{
Ticari Olarak Toz Formda Satılan Reishi Mantarlarının Biyoaktif Özellikleri
}

\author{
Ahmet Şükrü DEMİRCí ${ }^{1}$, Didem SÖZERİ ATIIK ${ }^{1 *}$ İbrahim PALABIYIK ${ }^{1}$, Mehmet GÜLCÜ
}

\begin{abstract}
Ganoderma lucidum (Reishi mushroom) has well known history of use with regards to ensuring health effects and longevity in Asian countries. Besides, it has an antioxidative protection system to protect the living organism from the action of free radicals. This study examines the bioactive properties of powder form of G. lucidum as a natural functional agent and the antimicrobial effects of the 5 different commercially sold powder of the G. lucidum mushrooms were investigated against various pathogenic bacteria and molds. For this purpose, the phenolic content, antioxidant capacity of G. lucidum samples were determined. The antimicrobial effects of the 5 different G. lucidum mushrooms against various food-related pathogenic bacteria (Escherichia coli ATCC 25922, Listeria monocytogenes ATCC 7644, Salmonella enterica subsp. enterica serovar Enteritidis ATCC 13076, Staphylococcus aureus ATCC 2592, Vibrio parahaemolyticus ATCC 17802) and molds (Aspergillus parasiticus NRRL 2999 and Aspergillus parasiticus NRRL 465) were expressed as a diameter (mm) of the inhibition zone. The values of total phenolic content of different $G$. lucidum samples ranged from 2.35 to $10.46 \mathrm{mg} \mathrm{GAE} \mathrm{g}^{-1}$. The scavenging activity of DPPH radicals of G. lucidum samples did not show any significant difference for samples 2,4 , and 5 . The same trend was observed between for ABTS+ results of these samples. The highest total phenolic content and antioxidative activity were observed in the sample 1 . The extracts of different G. lucidum samples demonstrated statistically significant antibacterial activity against $E$. coli ATCC 25922. Regarding the antifungal activity of $G$. lucidum samples, there were not found any significant differences when compared different samples. The results demonstrated that G. lucidum can be used as a functional food ingredient to improve the bioactive properties of foods.
\end{abstract}

Keywords: Reishi, Antimicrobial, DPPH, ABTS, Lingzhi

\footnotetext{
${ }^{1}$ Ahmet Şükrü Demirci, Department of Food Engineering, Namık Kemal University, Tekirdağ, Turkey. E-mail: ademirci@nku.edu.tr (DDrcID: 0000-0001-52528307

${ }^{1 *}$ Corresponding Author: Didem Sözeri Atik, Department of Food Engineering, Namık Kemal University, Tekirdağ, Turkey. E-mail: dsozeri@nku.edu.tr OrcID: 0000-0002-8547-7304.

${ }^{1}$ İbrahim Palabıyı, Department of Food Engineering, Namık Kemal University, Tekirdağ, Turkey. E-mail: ipalabiyik@nku.edu.tr (D) OrcID: 0000-0001-88501819 .

${ }^{2}$ Mehmet Gülcü, Balıkesir Food Control Laboratory, Karesi, Balıkesir, Turkey. E-mail: mehmet.gulcu@tarim.gov.tr (iDOrcID: 0000-0001-7862-7733. Atıf/Citation: Demirci, A.Ş., Sözeri Atik, D., Palabıyık, i., Gülcü, M. Bioactive Properties of Commercial Reishi Mushroom Products in Powder Form. Tekirda $\breve{g}$ Ziraat Fakültesi Dergisi, 18 (2), 273-281.

CBu çalışma Tekirdağ Namık Kemal Üniversitesi tarafından Creative Commons Lisansı (https://creativecommons.org/licenses/by-nc/4.0/) kapsamında yayınlanmıştır. Tekirdağ 2021 


\section{Özet}

Ganoderma lucidum (Reishi mantarı), Asya ülkelerinde sağlık etkileri ve uzun ömürlülüğü sağlamak için yaygın olarak bilinen bir kullanım geçmişine sahiptir. Ayrıca, canlı organizmayı serbest radikallerin etkisinden korumak için antioksidatif koruma sistemine de sahiptir. Bu çalışmada toz formunda G. lucidum'un doğal fonksiyonel ajanlar olarak biyoaktif özellikleri incelenmiş ve G. lucidum mantarlarının ticari olarak satılan 5 farklı tozunun çeşitli gıda patojeni bakterilere ve küflere karşı antimikrobiyal etkileri araştırılmıştır. Bu amaçla G. lucidum numunelerinin toplam fenolik içeriği, antioksidan kapasitesi de belirlenmiştir. 5 farklı G. lucidum mantarının antimikrobiyal etkileri, gıda ile ilgili çeşitli patojenik bakterilere (Escherichia coli ATCC 25922, Listeria monocytogenes ATCC 7644, Salmonella enterica subsp. enterica serovar Enteritidis ATCC 13076, Staphylococcus aureus ATCC 2592, Vibrio parahaemolyticus ATCC 17802) küflere (Aspergillus parasiticus NRRL 2999 ve Aspergillus parasiticus NRRL 465) karşı araştırılmış ve sonuçlar inhibisyon zon çapı (mm) olarak ifade edilmiştir. Farklı G. lucidum örneklerinin toplam fenolik içeriği değerlerinin 2.35 ila $10.46 \mathrm{mg} \mathrm{GAE} \mathrm{g}^{-1}$ arasında değiştiği bulunmuştur. G. lucidum numunelerinin DPPH radikallerine karşı antioksidan aktivitesi araştırıldığında; 2, 4 ve 5 numaralı örnekler arasında önemli bir fark gözlemlenmemiştir. Bu numunelerin $\mathrm{ABTS}^{+}$sonuçları için de aynı eğilim olduğu tespit edilmiştir. En yüksek toplam fenolik içerik ve antioksidatif aktivite G. lucidum'un 1 numaralı örneğinde belirlenmiștir. Farklı G. lucidum örneklerinin ekstraktları, E. coli ATCC 25922'ye karşı istatistiksel olarak anlamlı antibakteriyal aktivite gösterirken ( $<<0.05)$, G. lucidum örneklerinin antifungal aktivitesi ile ilgili olarak, farklı örnekler karşılaştırıldığında istatistiksel olarak anlamlı bir farklılık bulunamamıştır ( $p>0.05)$. Elde edilen sonuçlara göre, G. lucidum'un gıdaların biyoaktif özelliklerini geliştirmek için fonksiyonel bir gıda bileşeni olarak kullanılabileceğini görülmektedir.

Anahtar Kelimeler: Reishi, Antimikrobiyal, DPPH, ABTS, Lingzhi 


\section{Introduction}

The increasing world population has various problems related to nutrition and health. Despite the great advances in science and technology, the unconscious consumption of natural resources and the economic difficulties encountered have made it necessary to use natural resources for multiple purposes. On the other hand, the natural and synthetic antibiotics developed so far have been ineffective in the fight against infectious diseases as a result of the resistance of microorganisms, and various side effects have led the science of medicine to discover new and natural antimicrobial substances (Karaman et al., 2003).

According to previous scientific research, it has been determined that some macrofungus species produce various chemical compounds with antibacterial, antifungal, antiviral, and antiprotozoal properties. Antimicrobial effects of macrofungi are caused by some phenolic compounds, purines and pyrimidines, quinones, terpenoids, and phenylpropanoid derivative antagonistic substances synthesized by the fungal metabolism (Benedict and Brady, 1972). Many fungal species are used in the world for therapeutic purposes such as Ganoderma lucidum (Lingzhi), Ophiocordyceps (Cordyceps) (Paterson, 2006), Lentinula edodes (Shiitake), Piptoporus betulinus (Birch polypore/ bracket), Grifola frondosa (Hen of the woods/Maitake), Inonotus obliquus (Chaga) ve Agaricus subrufescens (Almond mushroom) (De Silva et al., 2012; Wasser, 2011).

G. lucidum which has been known as the immortality plant in China and also it is known as Reishi or Mannentake in Japan. Moreover, Ganoderma lucidum is known as Ling-Zhi in China and it represents good luck (Kino et al., 1989). The health-promoting effects of the mushroom have been known for centuries. The modern scientific studies have also confirmed that $G$. lucidum has various health effects such as immune-regulating, antitumor, antioxidant, antimicrobial, cardiovascular, antiallergenic, liver-protecting and antidiabetic (Berovič et al., 2003; Li et al., 2010; Wasser, 2010). It has been reported that the bioactive components of Ganoderma species such as polysaccharides, terpenoids, sterols, lectins proteins, nucleotides, and fatty acids are the main cause of the beneficial effects of the mushroom on human health (Yeung, 2004). Furthermore, Kim and Kim (1999) demonstrated that G. lucidum was non-toxic to healthy cells, even if taken at high doses.

Besides, Ganoderma species produce a wide variety of potential intra-cellular and extra-cellular antimicrobial components (Liu et al., 2009). Several studies have revealed the antimicrobial activity of G. lucidum (Gao et al., 2005; Quereshi et al., 2010; Sheena et al., 2003). G. lucidum products are sold commercially in different forms such as tea, dietary supplements and powders. These products are obtained from mycelia, fruit body and spores parts of the product.

It is known to have an antioxidative protection system to protect the living organism from the action of free radicals. In some cases, free radicals appear to be excessive in the body due to the antioxidative protective system not working well. This causesdamage to the body such as the amount of free radicals increases, aging accelerates, cell death, tissue death, and damage to brain vessels. Recent evidence suggests that G. lucidum contributes to the removal of reactive oxygen species by increasing the superoxide dismutase and catalase enzyme activity (Ajith et al., 2009; Smina et al., 2011).

The aim of this study was to investigate the antimicrobial effects, of the 5 different commercially sold powders of the G. lucidum mushrooms against various food-related pathogenic bacteria and molds, thereby finding new sources in the fight against infectious diseases. Besides, this study was also designed to determine total phenolic contents and antioxidant capacities of G. lucidum samples.

\section{Materials and Methods}

\subsection{Materials}

Five different powder of the commercial Lingzhi (G. lucidum) products were purchased from different commercial firms. Folin-Ciocalteu reagent, sodium carbonate, methanol, $\mathrm{DPPH}$, and $\mathrm{ABTS}^{+}$were provided from Merck KGaA (Darmstadt, Germany). 


\subsection{Extraction procedure of Ganoderma lucidum samples for antioxidant and phenolic content analysis}

One $\mathrm{g}$ of sample was mixed with methanol $99 \%$ to the ratio of 1:9 (reishi: methanol) and extracted with using a rotary shaker, the mixture was shaken (Rotator, Dragon Laboratory Instruments) at $70 \mathrm{rpm}$ and room temperature for $2 \mathrm{~h}$. Then, at $4500 \mathrm{rpm}$ at $4{ }^{\circ} \mathrm{C}$, the extracts were centrifuged for $15 \mathrm{~min}$ and to remove suspended materials, the extracts were filtered through Whatman No.1 filter and stored at $4{ }^{\circ} \mathrm{C}$ until analysis. All extractions were performed in triplicate.

\subsection{Determination of total phenolic content}

The total phenolic content (TPC) of samples was evaluated according to the procedure reported by (Singleton et al. 1999; Bozdemir et al. 2021). For analysis, $100 \mu \mathrm{L}$ of the extracted sample was mixed with $7.5 \mathrm{~mL}$ of distilled water. $500 \mu \mathrm{L}$ Folin-Ciocalteu reagent and $1 \mathrm{ml}$ of stock solution of $\mathrm{Na}_{2} \mathrm{CO}_{3}$ were added to the mixture. The absorbance of samples was measured at $720 \mathrm{~nm}$ and results were given as $\mathrm{mg} \mathrm{GAE}^{-1}$. All trials were duplicated.

\subsection{Antioxidant activity}

$\mathrm{ABTS}^{+}$(2,2'-Azino-bis-3-ethylbenzothiazoline-6-sulfonic) and DPPH (1,1-diphenyl-2-picrylhydrazyl) radical scavenging methods were used to determine the antioxidant activity of G. lucidum samples. DPPH radical scavenging activity was measured at $517 \mathrm{~nm}$ and results were expressed as $\mu \mathrm{mol}$ Trolox equivalent $\mathrm{g}^{-1}$ according to the method as previously used (Brand-Williams et al. 1995). ABTS ${ }^{+}$radical scavenging method was used at 734 $\mathrm{nm}$ by adapting the procedure used by Re et al. (1999) and Durmus et al., (2020). Results were given as $\mu \mathrm{mol}$ Trolox equivalent $\mathrm{g}^{-1}$. All trials were duplicated.

\subsection{Antimicrobial activity}

For antimicrobial analysis, 5 food-based pathogenic bacteria and 2 fungi were used. Escherichia coli ATCC 25922, Listeria monocytogenes ATCC 7644, Salmonella enterica subsp. enterica serovar Enteritidis ATCC 13076 and Staphylococcus aureus ATCC 2592, Vibrio parahaemolyticus ATCC 17802, Aspergillus parasiticus NRRL 2999 and Aspergillus parasiticus NRRL 465 were obtained from the Food Microbiology Laboratory of Namık Kemal University, Food Engineering Department. The agar disc diffusion method was used for the determination of antimicrobial activities of the extracts in question (NCCLS, 1997; Apaydin and Gümüş, 2018). The stock solution of the overnight culture was standardized to $0.5 \mathrm{McFarland}$ scale. Mueller Hinton Agar (Merck, Darmstadt, Germany) and Potato Dextrose Agar (Merck, Darmstadt, Germany) were used to perform antimicrobial analysis. A suspension of the tested microorganism $\left(0.1 \mathrm{~mL}\right.$ of $10^{8}$ cells per $\mathrm{ml}$ of bacteria and $10^{4}$ spore $/ \mathrm{mL}$ of fungi) was spread on the solid media plates. Filter paper discs ( $6 \mathrm{~mm}$ in diameter) were impregnated with $20 \mu \mathrm{L}$ of the extracts and placed on the inoculated plates. After the incubation at $37{ }^{\circ} \mathrm{C}$ for 24 hours, inhibition zones were measured by a calliper. Tests were carried out in triplicate.

\subsection{Statistical analysis}

The TPC, antioxidant, and antimicrobial activity results of Ganoderma lucidum samples were analyzed with one-way ANOVA to find significant differences by using JMP statistical software (State College PA, USA). For compare means, the Tukey multiple comparison test was used at $95 \%$ confidence level. Values are presented as means \pm SD of three parallel measurements.

\section{Results and Discussion}

\subsection{Total phenolic contents of samples}

The results of the total phenolic content of G. lucidum are demonstrated in Figure 1. When compared to TPC values of different samples of G. lucidum, it was observed that Sample 1 had $10.46 \mathrm{mg} \mathrm{GAE} \mathrm{g}^{-1}$ TPC value which was significantly higher than other samples $(\mathrm{p}<0.05)$. The TPCs of G. lucidum samples were found between 2.35 $10.46 \mathrm{mg} \mathrm{GAE} \mathrm{g}^{-1}$. Furthermore, it is apparent from Figure 1 that there was no significant difference $(\mathrm{p}>0.05)$ between the samples 4 and 5 whereas they were followed for TPC values by samples 2 and 3 , respectively. 


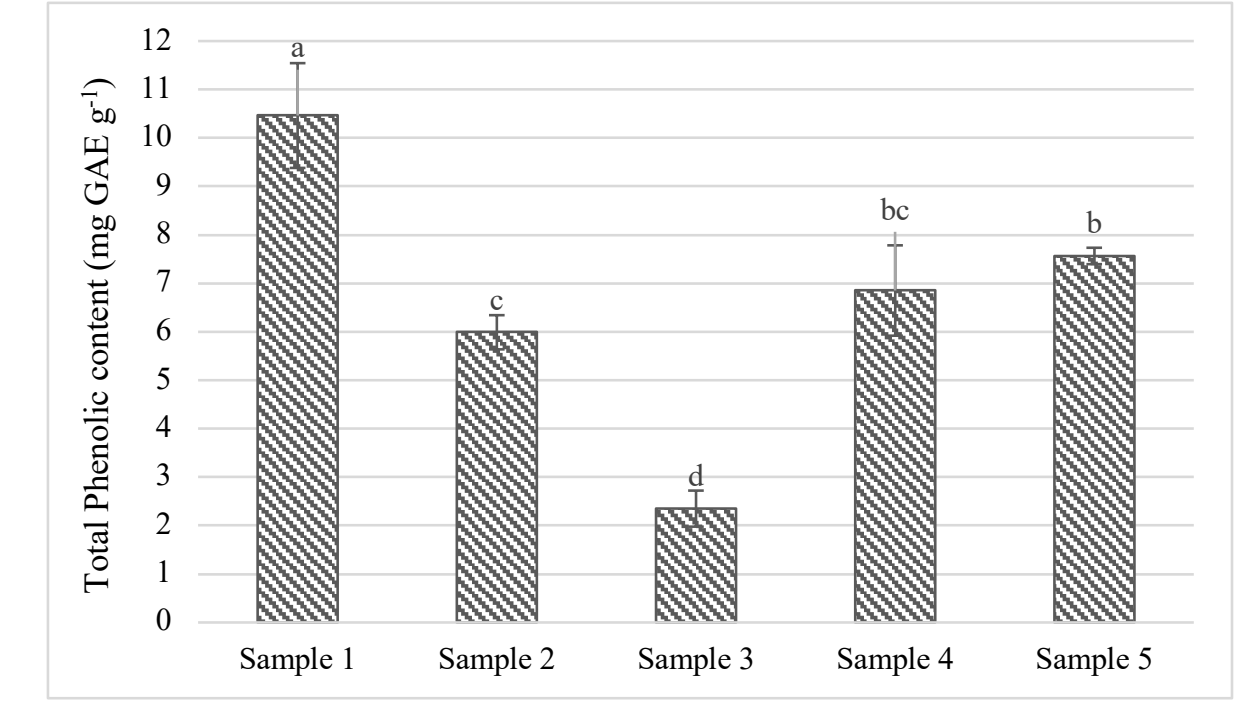

Results are expressed as the mean and the error bars represent standard deviation of means $(n=3)$ Lower-case letters present the differences between the samples $(\mathrm{p}<0.05)$

Figure 1. Total phenolic content of Ganoderma lucidum samples

Ćilerdžić et al. (2014) reported that there was a difference between various G. lucidum samples, while phenolic content of the samples cultivated on wheat straw varied from $28.06 \mathrm{mg} \mathrm{GAE} / \mathrm{g}$ to $52.15 \mathrm{mg} \mathrm{GAE} \mathrm{g}^{-1}$. However, the commercial strain of G. lucidum sample was found as $33.42 \mathrm{mg} \mathrm{GAE} \mathrm{g}^{-1}$. On contrary, the total phenolic results of samples which are used in the present study were found lower than the other studies. For the determination of the effect of extraction solution on G. lucidum samples, Celık et al. (2014) were used as methanol and ethanol for the extraction. They found that there was no significant difference between the two extraction materials.

\subsection{Antioxidant activity}

The result of TPC values was found consistent with the antioxidant activity of G. lucidum samples. DPPH and $\mathrm{ABTS}^{+}$radical scavenging abilities of G. lucidum samples are given in Figure 2 and Figure 3, respectively. According to Figure 2 and 3, correlating with the phenolic content of $10.46 \mathrm{mg} \mathrm{GAE} \mathrm{g}^{-1}$ (see Fig. 1), sample 1 also showed the highest antioxidant activity when compared to other samples.

The scavenging activity of DPPH radicals of G. lucidum samples was ranged from 0.81 to $9.98 \mu \mathrm{mol}$ Trolox $\mathrm{g}^{-1}$. In addition, the results of samples 2,4 and 5 did not show any significant difference in DPPH scavenging activity ( $\mathrm{p}>0.05)$. However, sample 3 resulted in the lowest value of DPPH. There are similarities with the results of Veljović et al. (2017) who found the antioxidant activity of G. lucidum ethanol extracts was ranged from 1.40 to $3.07 \mathrm{mmol}$ Trolox Equivalent. The content of Ganoderma species such as polysaccharides, glycoproteins, and polysaccharidic extracts is an important factor for its antioxidant property (Ferreira et al., 2015). Besides, researchers reported that GLP2 (G. lucidum polysaccharides) which is a polysaccharide from G. lucidum showed only $9.5 \%$ lower antioxidant activity from BHT (Butylated hydroxytoluene). It showed that components of $G$. lucidum can be used as a potential antioxidant (Lim et al., 2011; Ma et al., 2013).

The same trend was observed between DPPH and $\mathrm{ABTS}^{+}$results of samples. There were no significant differences between samples 2,4 and $5(\mathrm{p}<0.05)$ whereas sample 1 had higher ABTS+ scavenging activity. The effect of $\mathrm{ABTS}^{+}$scavenging activity on our different samples were found between 9.71-107.47 $\mu$ mol Trolox $\mathrm{g}^{-1}$. Although these results differed from a published study of Sudheer et al. (2018), they found that the $\mathrm{ABTS}^{+}$radical scavenging activities of G. lucidum samples were ranged from 32.5 to $38.42 \mathrm{mg}^{\text {Trolox }} \mathrm{g}^{-1}$ dry weight. On the other hand, Islam et al. (2016) reported that the results of $\mathrm{ABTS}^{+}$radical scavenging activity were found as 12.94 $\mu$ mol Trolox $\mathrm{g}^{-1}$ which supported the present study. A possible explanation for this might be the different composition of samples. 


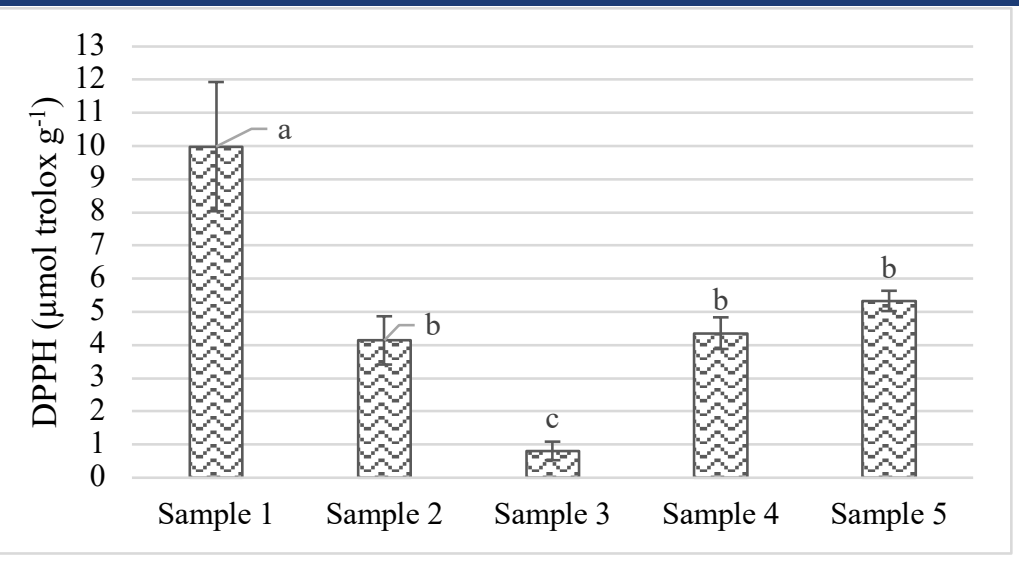

Results are expressed as the mean and the error bars represent standard deviation of means $(n=3)$. Lower-case letters present the differences between the samples $(\mathrm{p}<0.05)$.

Figure 2. DPPH radical scavenging activity of Ganoderma lucidum samples

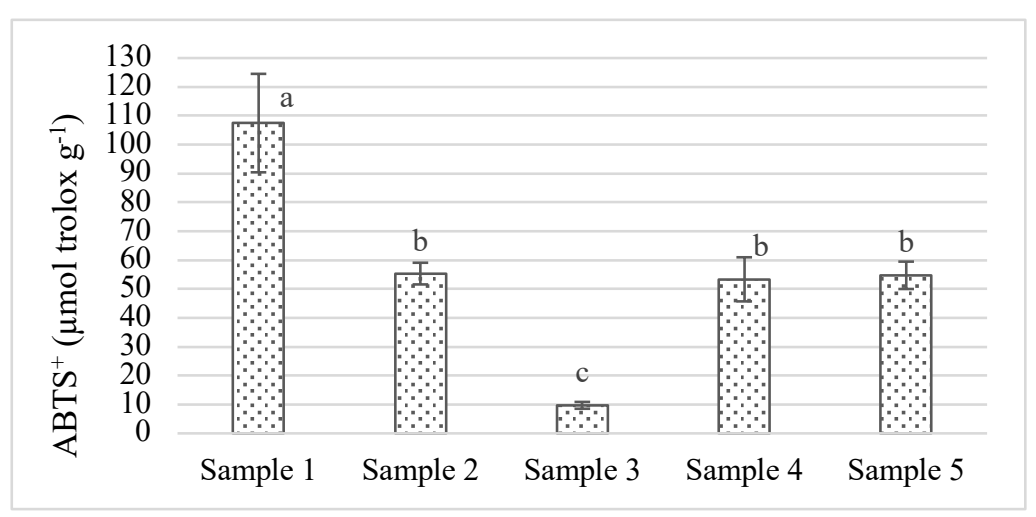

Results are expressed as the mean and the error bars represent standard deviation of means $(n=3)$. Lower-case letters present the differences between the samples $(\mathrm{p}<0.05)$.

Figure 3. ABTS $^{+}$radical scavenging activity of Ganoderma lucidum samples

Studies showed that G. lucidum increases the activity of super oxide dismutase and catalase which are enzymes involved in removing harmful reactive oxygen species (ROS) (Ajith et al., 2009; Smina et al., 2011).

\subsection{Antimicrobial analysis}

Antimicrobial potential of G. lucidum extracts was evaluated by disc-diffusion method and is shown in Table 1. Sample 3 was found to be most effective with high inhibition zones compared to the other samples against bacterial strains under the treatment conditions tested. However, there were not significant differences between mushroom samples against pathogenic bacteria except E. coli ATCC 25922.

The extracts of different commercial G. lucidum samples demonstrated various antibacterial activity against $E$. coli ATCC $25922(\mathrm{p}<0.05)$. G. lucidum samples produced inhibition zones in the range of 7.61-14.33 mm. This finding is in agreement with the study of Ćilerdžić et al. (2014), who reported that the antibacterial activity zones of different G. lucidum samples ranged from 10.5 to $13.3 \mathrm{~mm}$. In the present study, the higher susceptibility of $E$. coli ATCC 25922 was observed for samples 3 and 4. Also it was followed by samples 2 and 5. Sample 1 was found to have lower antibacterial activity against $E$. coli ATCC 25922.

S. aureus is a pathogen which can create biofilms on the surface of food products (Shi and Zhu, 2009). As in Table 2, there was not a significant difference between G. lucidum samples $(\mathrm{p}>0.05)$. The measured ranges of antibacterial activity of samples against $S$. aureus ATCC 2592 were found from 8.71 to $11.62 \mathrm{~mm}$. The antibacterial activity of G. lucidum samples against $S$. aureus was found lower than one revealed by Ćilerdžić et al. (2014). S. Enteritidis ATCC 13076 was inhibited by G. lucidum samples in the inhibition range of 9.13-11.15 
$\mathrm{mm}$. On the other hand, no significant differences were found between G. lucidum samples ( $\mathrm{p}>0.05)$. This study produced results which corroborated the findings of a great deal of the previous work. As Celik et al. (2014) mentioned in their research, ethanolic and methanolic extracts of G. lucidum showed antibacterial activity against $S$. Enteritidis ATCC 13076. They found the inhibition diameter of G. lucidum samples as $12 \mathrm{~mm}$ which is similar to the present study.

Table 1. Antimicrobial activity results of different Ganoderma lucidum samples

\begin{tabular}{|c|c|c|c|c|c|}
\hline \multirow{3}{*}{ Microorganisms } & \multicolumn{5}{|c|}{ Inhibition zone diameter (mm) } \\
\hline & \multicolumn{5}{|c|}{ G. lucidium samples } \\
\hline & Sample 1 & Sample 2 & Sample 3 & Sample 4 & Sample 5 \\
\hline Escherichia coli ATCC 25922 & $7.61 \pm 1.13 b$ & $10.85 \pm 2.43 \mathrm{ab}$ & $14.33 \pm 0.38 \mathrm{a}$ & $13.56 \pm 4.38 \mathrm{a}$ & $10.25 \pm 2.23 \mathrm{ab}$ \\
\hline $\begin{array}{l}\text { Staphylococcus aureus ATCC } \\
\quad 2592\end{array}$ & $8.71 \pm 2.00$ & $8.83 \pm 2.06$ & $9.17 \pm 1.63$ & $11.62 \pm 1.89$ & $9.88 \pm 0.80$ \\
\hline $\begin{array}{l}\text { Salmonella enterica subsp. } \\
\text { enterica serovar Enteritidis } \\
\text { ATCC } 13076\end{array}$ & $9.13 \pm 2.50$ & $11.15 \pm 1.42$ & $10.80 \pm 0.88$ & $9.86 \pm 2.80$ & $10.02 \pm 1.02$ \\
\hline $\begin{array}{l}\text { Listeria monocytogenes ATCC } \\
\quad 7644\end{array}$ & $10.57 \pm 2.19$ & $11.44 \pm 2.96$ & $11.83 \pm 1.96$ & $11.66 \pm 2.40$ & $9.36 \pm 1.64$ \\
\hline $\begin{array}{l}\text { Vibrio parahaemolyticus ATCC } \\
\quad 17802\end{array}$ & $11.44 \pm 3.14$ & $11.63 \pm 3.49$ & $13.34 \pm 4.36$ & $10.30 \pm 2.88$ & $10.41 \pm 2.79$ \\
\hline $\begin{array}{l}\text { Aspergillus parasiticus NRRL } \\
2999\end{array}$ & $12.46 \pm 0.47$ & $12.73 \pm 1.15$ & $12.82 \pm 4.11$ & $13.85 \pm 2.10$ & $12.43 \pm 1.18$ \\
\hline $\begin{array}{l}\text { Aspergillus parasiticus NRRL } \\
465\end{array}$ & $13.13 \pm 0.75$ & $13.67 \pm 1.00$ & $13.20 \pm 1.15$ & $11.03 \pm 1.45$ & $12.00 \pm 1.71$ \\
\hline
\end{tabular}

Results are expressed as the mean \pm standard deviation $(n=3)$

Different letters in the same row are significantly different $(\mathrm{p}<0.05)$

Antimicrobial activity against $V$. parahaemolyticus ATCC 17802 was manifested as zone diameter between 9.36-11.83 $\mathrm{mm}$ depending on the G. lucidum sample studied. However, there was no significant difference between samples against this bacterium $(\mathrm{p}>0.05)$.

The antifungal activity of G. lucidum samples on A.parasiticus NRRL 2999 and A. parasiticus NRRL 465 is presented in Table 1. Regarding the antifungal activity of G. lucidum samples, there were no significant differences when compared different samples ( $\mathrm{p}>0.05$ ). The results showed that the inhibition diameter of $G$. lucidum samples was found from 12.43 to $13.85 \mathrm{~mm}$ and 11.03-13.67 mm for A. parasiticus NRRL 2999 and A. parasiticus NRRL 465 , respectively. Terpenoids are reported to be one of the major antimicrobial constituents of Ganoderma species (Gao et al., 2003).

\section{Conclusion}

In this study, comparison of total phenolic content, antimicrobial and antioxidant properties of 5 commercial Lingzhi (G. lucidum) products currently available on the market was studied. The findings of this study indicated that there was a difference between samples in terms of the total phenolic content, antioxidative power and antibacterial activity against $E$. coli ATCC 25922 . The results obtained from the disc diffusion method, indicated that the microorganisms $S$. aureus was the most resistant microorganism tested, showing the smallest inhibition zones, in the presence of G. lucidum extracts. As a result of the high phenolic content, antioxidant power and antimicrobial activity of the samples, this study showed that G. lucidum can be a potential candidate as a functional food ingredient to improve the biological activity of food products. 


\section{References}

Ajith, T., Sudheesh, N., Roshny, D., Abishek, G., Janardhanan, K. (2009). Effect of Ganoderma lucidum on the activities of mitochondrial dehydrogenases and complex I and II of electron transport chain in the brain of aged rats. Experimental gerontology, 44(3), 219-223.

Apaydin, H. and Gümüş, T. (2018). Inhibitory effect of propolis (bee gum) against staphylococcus aureus bacteria isolated from instant soups 1. Journal of Tekirdag Agricultural Faculty, 15(1), 67-75.

Benedict, R. and Brady, L. (1972). Antimicrobial activity of mushroom metabolites. Journal of pharmaceutical sciences, 61(11), 1820-1822.

Berovič, M., Habijanič, J., Zore, I., Wraber, B., Hodžar, D., Boh, B., Pohleven, F. (2003). Submerged cultivation of Ganoderma lucidum biomass and immunostimulatory effects of fungal polysaccharides. Journal of Biotechnology, 103(1), 77-86.

Brand-Williams, W., Cuvelier, M.-E., Berset, C. (1995). Use of a free radical method to evaluate antioxidant activity. LWT-Food science and Technology, 28(1), 25-30.

Bozdemir, M., Kamer, D. D. A., Akgül, G., Gümüş, T. (2021) Farklı hammaddelerden üretilen sirkelerin bazı fizikokimyasal ve fonksiyonel özellikleri. Tekirdağ Ziraat Fakültesi Dergisi, 18(1), 32-44.

Celık, G. Y., Onbaslı, D., Altınsoy, B., Allı, H. (2014). In vitro antimicrobial and antioxidant properties of Ganoderma lucidum extracts grown in Turkey. European Journal of Medicinal Plants, 709-722.

Ćilerdžić, J., Vukojević, J., Stajić, M., Stanojković, T., \& Glamočlija, J. (2014). Biological activity of Ganoderma lucidum basidiocarps cultivated on alternative and commercial substrate. Journal of ethnopharmacology, 155(1), 312-319.

De Silva, D. D., Rapior, S., Fons, F., Bahkali, A. H., \& Hyde, K. D. (2012). Medicinal mushrooms in supportive cancer therapies: an approach to anti-cancer effects and putative mechanisms of action. Fungal Diversity, 55(1), 1-35.

Durmus, F., Ozcan-Sinir, G., Sahin, K. G., Çopur, O. U. (2020). Determination of Physicochemical Properties and Antioxidant Capacity of Artichoke (Cynara cardunculus var. Scolymus L.) Jam Produced from Different Cultivars.

Ferreira, I. C., Heleno, S. A., Reis, F. S., Stojkovic, D., Queiroz, M. J. R., Vasconcelos, M. H., Sokovic, M. (2015). Chemical features of Ganoderma polysaccharides with antioxidant, antitumor and antimicrobial activities. Phytochemistry, 114, 38-55.

Gao, Y., Tang, W., Gao, H., Chan, E., Lan, J., Li, X., Zhou, S. (2005). Antimicrobial activity of the medicinal mushroom Ganoderma. Food Reviews International, 21(2), 211-229.

Gao, Y., Zhou, S., Huang, M., and Xu, A. (2003). Antibacterial and antiviral value of the genus Ganoderma P. Karst. species (Aphyllophoromycetideae): a review. International Journal of Medicinal Mushrooms, 5(3).

Islam, T., Yu, X., Xu, B. (2016). Phenolic profiles, antioxidant capacities and metal chelating ability of edible mushrooms commonly consumed in China. LWT - Food Science and Technology, 72, 423-431. doi:https://doi.org/10.1016/i.lwt.2016.05.005

Karaman, İ., Şahin, F., Güllüce, M., Öğütçü, H., Şengül, M., Adıgüzel, A. (2003). Antimicrobial activity of aqueous and methanol extracts of Juniperus oxycedrus L. Journal of Ethnopharmacology, 85(2), 231-235. doi:https://doi.org/10.1016/S0378-8741(03)00006-0

Kim, K. C. and Kim, I. (1999). Ganoderma lucidum extract protects DNA from strand breakage caused by hydroxyl radical and UV irradiation. International Journal of Molecular Medicine, 4(3), 273-280.

Kino, K., Yamashita, A., Yamaoka, K., Watanabe, J., Tanaka, S., Ko, K., Tsunoo, H. (1989). Isolation and characterization of a new immunomodulatory protein, ling zhi-8 (LZ-8), from Ganoderma lucidium. Journal of Biological Chemistry, 264(1), 472-478.

Li, W. J., Nie, S. P., Chen, Y., Xie, M. Y., He, M., Yu, Q., Yan, Y. (2010). Ganoderma atrum polysaccharide protects cardiomyocytes against anoxia/reoxygenation-induced oxidative stress by mitochondrial pathway. Journal of cellular biochemistry, 110(1), 191-200.

Lim, D.-H., Choi, D., Choi, O.-Y., Cho, K.-A., Kim, R., Choi, H.-S., Cho, H. (2011). Effect of Astragalus sinicus L. seed extract on antioxidant activity. Journal of Industrial and Engineering Chemistry, 17(3), 510-516.

Liu, D., Hu, Z., Liu, Z., Yang, B., Tu, W., Li, L. (2009). Chemical composition and antimicrobial activity of essential oil isolated from the cultured mycelia of Ganoderma japonicum. Journal of Nanjing Medical University, 23(3), 168-172.

Ma, C.-w., Feng, M., Zhai, X., Hu, M., You, L., Luo, W., Zhao, M. (2013). Optimization for the extraction of polysaccharides from Ganoderma lucidum and their antioxidant and antiproliferative activities. Journal of the Taiwan Institute of Chemical Engineers, 44(6), 886-894. doi:https://doi.org/10.1016/j.jtice.2013.01.032

NCCLS (1997). Performance Standards for Antimicrobial Disk Susceptibility Tests, 6th Edn, Approved Standards. Document M2-A6. Wayne, PA: NCCLS

Paterson, R. R. M. (2006). Ganoderma-a therapeutic fungal biofactory. Phytochemistry, 67(18), 1985-2001.

Quereshi, S., Pandey, A., Sandhu, S. (2010). Evaluation of antibacterial activity of different Ganoderma lucidum extracts. J Sci Res, 3, 9-13. 
Re, R., Pellegrini, N., Proteggente, A., Pannala, A., Yang, M., Rice-Evans, C. (1999). Antioxidant activity applying an improved ABTS radical cation decolorization assay. Free radical biology and medicine, 26(9-10), 1231-1237.

Sheena, N., Ajith, T., Mathew, A., Janardhanan, K. (2003). Antibacterial activity of three macrofungi, Ganoderma lucidum, Navesporus floccosa and Phellinus rimosus occurring in South India. Pharmaceutical biology, 41(8), 564-567.

Shi, X. and Zhu, X. (2009). Biofilm formation and food safety in food industries. Trends in Food Science \& Technology, 20(9), 407-413.

Singleton, V. L., Orthofer, R., Lamuela-Raventós, R. M. (1999). Analysis of total phenols and other oxidation substrates and antioxidants by means of folin-ciocalteu reagent. In Methods in enzymology (Vol. 299, pp. 152-178): Elsevier.

Smina, T., De, S., Devasagayam, T., Adhikari, S., Janardhanan, K. (2011). Ganoderma lucidum total triterpenes prevent radiation-induced DNA damage and apoptosis in splenic lymphocytes in vitro. Mutation Research/Genetic Toxicology and Environmental Mutagenesis, $726(2), 188-194$

Sudheer, S., Taha, Z., Manickam, S., Ali, A., Cheng, P. G. (2018). Development of antler-type fruiting bodies of Ganoderma lucidum and determination of its biochemical properties. Fungal Biology, 122(5), 293-301. doi:https://doi.org/10.1016/i.funbio.2018.01.007

Veljović, S., Veljović, M., Nikićević, N., Despotović, S., Radulović, S., Nikšić, M., Filipović, L. (2017). Chemical composition, antiproliferative and antioxidant activity of differently processed Ganoderma lucidum ethanol extracts. Journal of food science and technology, 54(5), 1312-1320.

Wasser, S. P. (2010). Medicinal mushroom science: history, current status, future trends, and unsolved problems. International Journal of Medicinal Mushrooms, 12(1).

Wasser, S. P. (2011). Current findings, future trends, and unsolved problems in studies of medicinal mushrooms. Applied microbiology and biotechnology, 89(5), 1323-1332.

Yeung, W. (2004). Chemical and biochemical basis of the potential anti-tumor properties of Ganoderma lucidum. Curr Top Nutraceut Res, 2, $67-77$ 